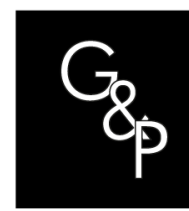

\title{
The evolution of studies on information technology and organizational agility: a bibliometric analysis
}

\section{A evolução dos estudos sobre tecnologia da informação e agilidade organizacional: uma análise bibliométrica}

\author{
Henrique Takashi Adati Tomomitsuㄹ (1), Renato de Oliveira Moraes ${ }^{2}$ (i) \\ ${ }^{1}$ Universidade de São Paulo - USP, Escola Politécnica, Programa de Pós-graduação em Gestão em Tecnologia da \\ Informação, São Paulo, SP, Brasil. E-mail: htomomitsu@yahoo.com.br \\ 2Universidade de São Paulo - USP, Escola Politécnica, São Paulo, SP, Brasil. E-mail: remo@usp.br
}

How to cite: Tomomitsu, H. T. A., \& Moraes, R. O. (2021). The evolution of studies on information technology and organizational agility: a bibliometric analysis. Gestão \& Produção, 28(2), e5294. https://doi.org/10.1590/1806-9649-2020v28e5294

\begin{abstract}
Studies on information technology and organizational agility has shown significant growth since the beginning of 2014, which may be an indicator that this theme is beginning to mature in the concerned literature, and increasingly has become the subject of researchers. In view of the presented scenario, the objective of this study is to introduce a synthesis of the literature panorama of the relation between the focused two constructs in the last years. The author (s) chose to employ a bibliometric analysis to understand the evolution of studies on that relation. We concluded that in the United States there is a great concentration of research on this subject, and the most recent publications, in general, occurred in relevant management and information management system journals. The identified studies mainly concentrate on the causal relationship between information technology (IT) and organizational agility from three perspectives: (1) the direct effect of IT capabilities on agility, (2) the moderating effect of IT capabilities on the relationship between other organizational capabilities and organizational agility, and (3) the indirect effect of IT on organizational agility mediated by other organizational capabilities. In addition, it was possible to identify organizational agility connected with three aspects: sensitivity, decision and responsiveness. Another contribution of the study is the construction of a framework based on the main study samples and the most recurrent keywords. It is possible to detect the three levels of analysis in the relation between the two previously mentioned constructs, besides bringing out the definitions used for each construct. An opportunity for future studies is to evaluate the taxonomy identified for organizational agility.
\end{abstract}

Keywords: Information technology; Organizational agility; Bibliometric study.

Resumo: Os estudos sobre tecnologia da informação e agilidade organizacional têm apresentado crescimento significativo desde o início de 2014, o que pode ser um indicador de que esse tema está começando a amadurecer na literatura pertinente e, cada vez mais, tem se tornando objeto de pesquisadores. Diante do cenário apresentado, o objetivo deste estudo é apresentar uma síntese do panorama da literatura sobre a relação dos dois construtos nos últimos anos. Os autores optaram por utilizar uma análise bibliométrica para compreender a evolução dos estudos sobre essa relação. Concluímos que nos Estados

Received Feb. 11, 2019 - Accepted June 28, 2019

Financial support: None.

This is an Open Access article distributed under the terms of the Creative Commons Attribution License, which permits unrestricted use, distribution, and reproduction in any medium, provided the original work is properly cited. 
Unidos existe uma grande concentração de pesquisas sobre o assunto, e as publicações mais recentes ocorreram em periódicos relevantes de gestão e sistemas de gestão da informação. Os estudos identificados concentram-se principalmente na relação causal entre tecnologia da informação ( $\mathrm{TI}$ ) e agilidade organizacional a partir de três perspectivas: (1) o efeito direto das capacidades de TI na agilidade, (2) o efeito moderador das capacidades de TI na relação entre outras capacidades organizacionais e agilidade organizacional e (3) o efeito indireto da $\mathrm{TI}$ na agilidade organizacional mediado por outras capacidades organizacionais. Além disso, foi possível identificar a agilidade organizacional ligada a três aspectos: sensibilidade, decisão e capacidade de resposta. Outra contribuição do estudo é a construção de um quadro baseado nas principais amostras do estudo e nas palavraschave mais recorrentes. É possível detectar os três níveis de análise na relação entre os dois construtos citados anteriormente, além de evidenciar as definições utilizadas para cada construto. Uma oportunidade para estudos futuros é avaliar a taxonomia identificada para agilidade organizacional.

Palavras-chave: Tecnologia da informação; Agilidade organizacional; Estudo bibliométrico.

\section{Introduction}

According to Tallon \& Pinsonneault (2011), with the recent market volatility expansion companies are increasingly concerned with (or about) identifying ways to achieve higher organizational agility indexes to respond promptly to market threats and opportunities.

Lee et al. (2015) and Felipe et al. (2016) define organizational agility as a key capability that enables a company to detect environmental changes and react efficiently and effectively to them.

Thus, companies seek means to improve organizational agility, one solution, according to Tallon \& Pinsonneault (2011), could be investing in information technologies (IT) aligned with business strategies. Several studies scrutinize how information technology impacts on organizational agility, but their results do not necessarily coincide with the current presupposition that it - impacts on organizational agility in a positive way. Lu \& Ramamurthy (2011) show that many studies point out that IT facilitates organizational agility, but in some scenarios, it can hinder its advance.

So, we infer that organizational agility studies have - important role for companies, as well as high potential to become an organizational agility drive. In addition, the present analysis of importance, evolution and trend of information technology and organizational agility synergy - may contribute to guide further researches, clearly rising in recent times, according to our results. As will be highlighted See in the result demonstration the highlighted lines showing the jump from 4 articles published in 2014 to 15 articles published in 2017.

In order to facilitate the understanding of the relationship between information technology and organizational agility, this study presents a synthesis of the concerned literature panorama in recent years by means of a bibliometric analysis and main trends and opportunities in the field.

The text is structured as following: section 2 focus on the applied methodology to perform the bibliometric study; section 3 reveals the analysis main results, and section 4 shares the main conclusions of the research. 


\section{Methodology}

\subsection{Data search}

We extracted the research database from ISI Web of Knowledge (Web of Science), reckoning that extraction generated by this database has high compatibility with the software that allowed the analysis of the selected articles. Another important factor is that articles available in this database belong to the Journal Citation Report (JCR) list.

The set of keywords we used in the search was: ("organizational agility" and "business analytics") or ("organizational agility" and "business intelligence") or ("organizational agility" and "information technology") or ("organizational agility" and "information system") or ("organizational agility" and "big data "). The inclusion of the terms" business analytics", "business intelligence" and "big data" in the searching process is due to their importance in the academic and professional communities in recent decades, according to Chen et al. (2012). Those authors highlight the opportunities associated with data and analysis in different organizations, enhancing the companies' significant interest in business intelligence and business analytics, which are often referred to as techniques, technologies, systems, practices, methodologies and applications. Some applications analyse critical business data to improve one's business and markets and regulate business decisions accelerating time to-market. After searching for the focus set of keywords, we identified 68 studies, 48 of which classified as articles, and built the sample we analyse throughout the study.

With the sample, we applied the following types of analysis:

- descriptive statistical;

- analysis of keywords;

- co-citation network analysis;

- content analysis.

See analyses in more detail in the next section.

\subsection{Data analysis}

The authors performed a set of descriptive statistical analyses on a sample of 48 articles using the Excel tool for data processing and Tableau as an initial experiment to generate the main indicator rank. This type of analysis allowed the study of the following aspects: the evolution of the number of publications within the year - to identify the evolution of studies on the subject over time; the period distribution of papers by country - to identify the main research hubs; the articles distribution by journals - to verify which ones pay more attention to the subject.

The importance of analysing the main keywords connected to information technology and organizational agility is to provide a framework that allows a better subject panorama visualization. The construction of this framework considers the keywords that had higher recurrence number, which can be observed in the words cloud, where the larger the word size, the higher its recurrence. We also read the main articles in the selected sample.

Co-citation analysis allows identifying the main authors referenced in the study sample, as well as the groups of the most relevant ones. This process had the support 
of VOSviewer software, which allowed to group the main authors, and for further analysis, the main author's article of each cluster.

Finally, we proceeded to the content analysis. In order to reduce the scope of studies to be analysed, we classified the articles using a weight indicator that considers the average number of publications and their impact factor in the Journal Citation Report (JCR), according to Carvalho et al. (2013) (Equation 1 - Calculation of article weight indicator):

Weight Indicator $=(1+$ JCR Impact Factor $) \times$ Average citation

After calculating the weight indicator, we drew a boxplot. Articles above 75th percentile present a weight indicator above 11.2493, and that corresponds to 12 articles, as demonstrated in Figure 1.

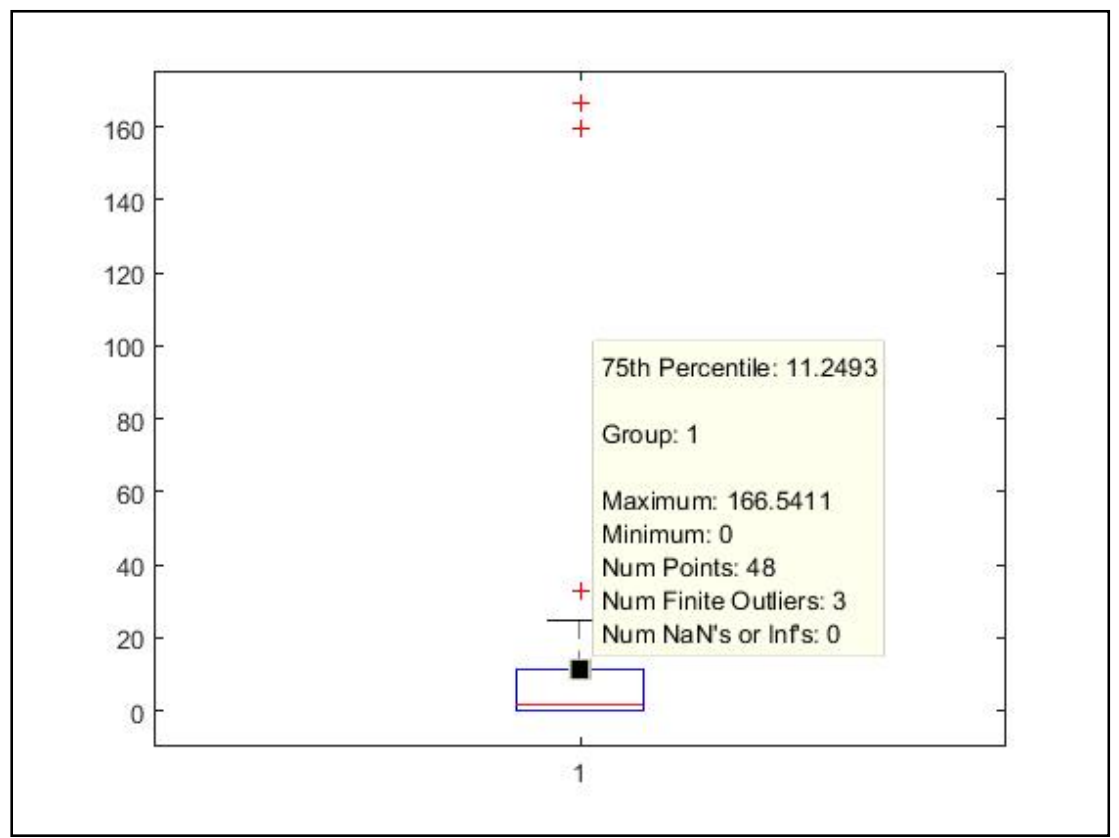

Figure 1. Boxplot demonstrating article weight indicators.

That modus operandi allowed the selection of the most relevant articles for content analysis, considering the number of citations in a period and the journal's impact factor.

\section{Presentation and discussion of results}

\subsection{Descriptive statistical analysis}

This analysis was performed on the sample of 48 articles. It can be noted from Figure 2 that the first studies were published in 2000, and the number of studies remained stable over the next 13 years. Only from the year 2014 there is a significant growth in the amount of studies focused on the theme of this study. 


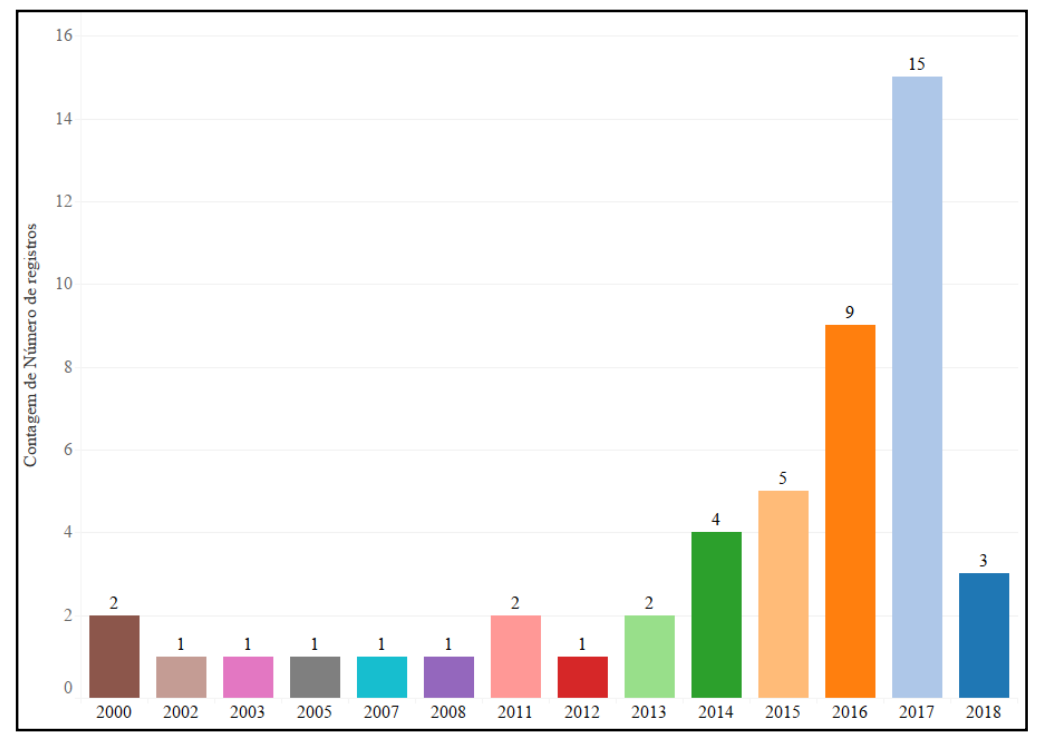

Figure 2. Evolution of the amount of studies over the years.

This growth in recent years may indicate that the relationship between information technologies and organizational agility is beginning to spread more widely in academia, indicating a great potential for studies on these two concepts together.

Regarding the journals in which the studies were published, it is possible to notice a great concentration on those that focus on studies that involve the aspect of information systems management and information management. The journals that have had the most publications overall and most recently are those that have a higher JCR impact factor. This is an important indicator that this subject is being considered by leading journals. Figure 3 presents the distribution of the publications of the sample articles in each journal.

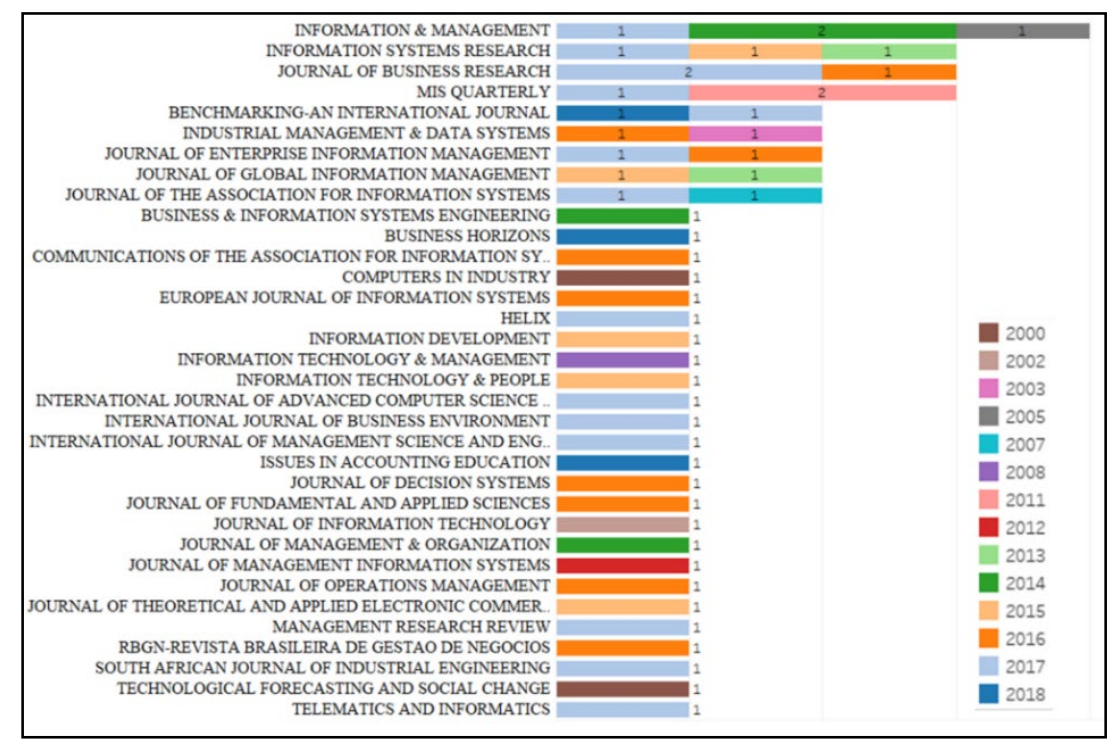

Figure 3. Distribution of articles by journal. 
There is a large concentration of studies on information technology and organizational agility in the United States, with 17 articles, representing $35.41 \%$ of the sample. The most recent studies are well distributed among the countries presented in Figure 4, which demonstrates that the topic is also starting to be of interest to researchers in more than one research centre.

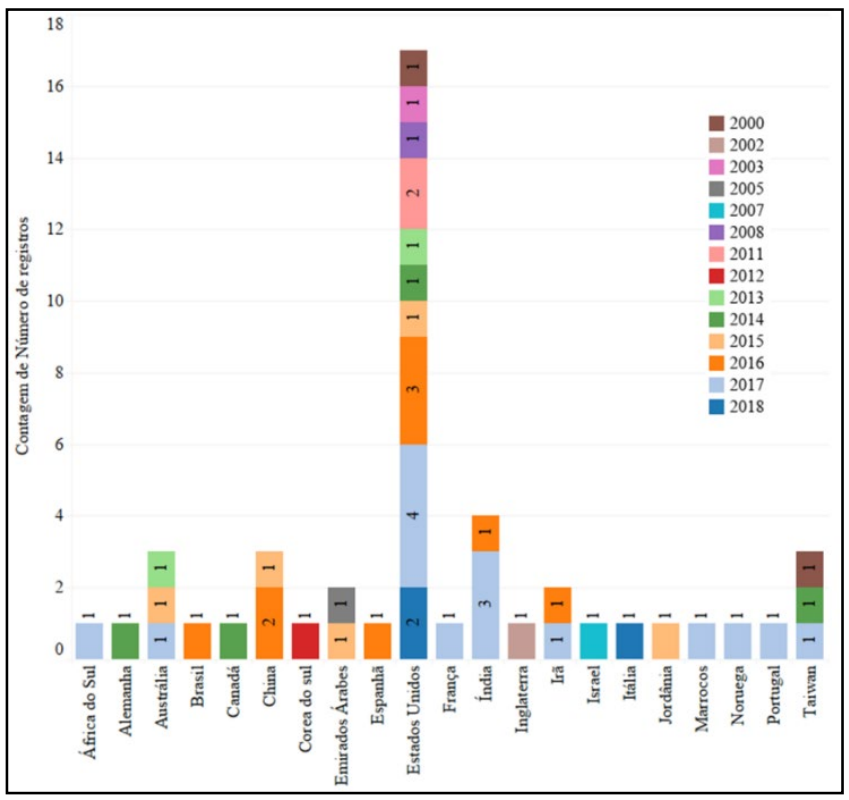

Figure 4. Main research hubs.

\subsection{Keyword analysis}

The classification of the main keywords of the initial sample studies allows us to identify the main topics related to the field of this study and to create a model that shows the relationship of the main identified topics with the key constructs of this study.

Figure 5 shows a keyword cloud of the articles analysed at this early stage. The reference to the words that appear most in the studies is associated with their size, for example, we can note that the word "Organizational agility" that was used in the search process is the term that appears most in the keywords of the studies.

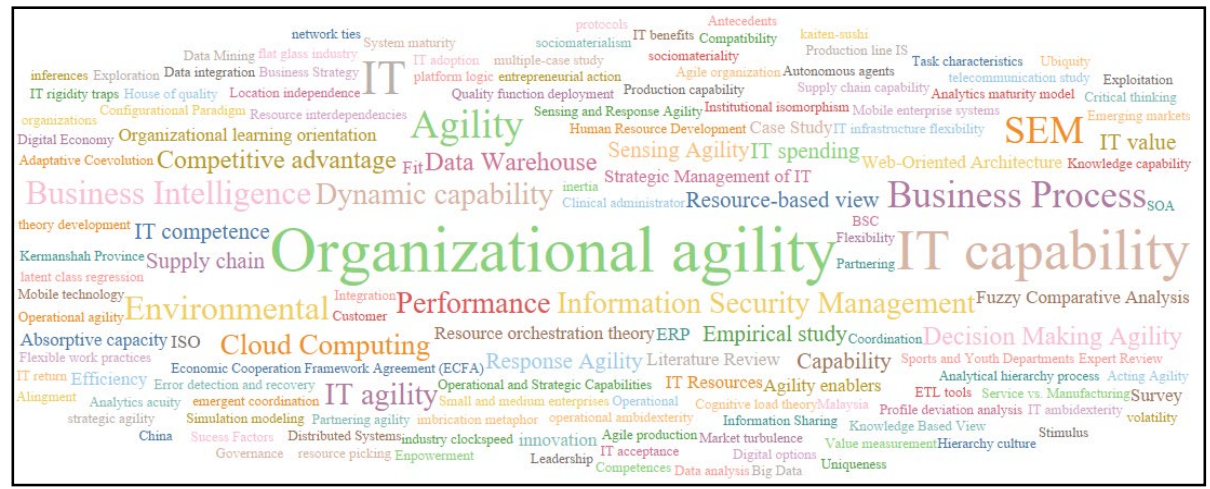

Figure 5. Keyword cloud. 
From the identified keywords, the theoretical model of the systematic literature review was elaborated considering the keywords that had a higher recurrence in the selected sample, as well as the reading of the main identified studies on this theme, which is presented in Figure 6.

In order to build this model, we first need to have a look at the proposed relationship between the two constructs analysed. Thus, according to the studies analysed, it can be highlighted that information technology is placed as an enabling element of organizational agility, but it is important to consider the environment in which the organization operates, which may influence its effect on organizational agility.

One term that has often appeared that needs to be highlighted is the business process. At first glance, it can be imagined that information technology can help in detecting events that enable business processes to be improved from more agile decision making, and thus contribute to organizational performance. This means that IT can indirectly impact organizational agility through its impacts on business processes.

The second step is to look deeper into each of the constructs individually. This allows a better understanding of how each construct is defined in the studies analysed.

Thus, the definition of the information technology construct in these studies is based on the assumptions established by some strategic approaches focused on the internal environment of the organization, such as resource-based view (RBV), dynamic capability and knowledge-based view. In this context, the term IT capability is widespread, and the survey is one of the keywords that most appeared. These approaches have a total synergy with the question of the results companies achieve as organizational performance (effectiveness and efficiency) and consequently the competitive advantage.

It is also possible to highlight the types of information technologies that stood out in the sample, which were business intelligence, cloud computing, data warehouse, enterprise resource planning (ERP).

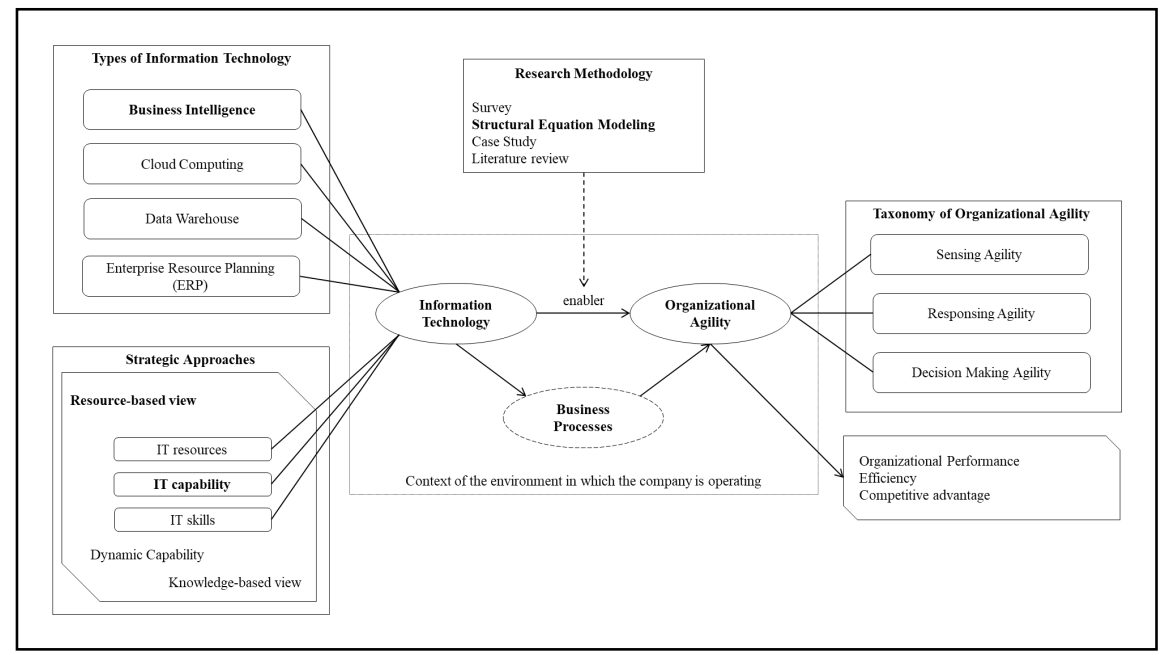

Figure 6. Framework arising from the systematic literature review.

Regarding the organizational agility construct, it is possible to notice terms associated with a possible taxonomy of this construct, in which it is the composition of agility in event detection, agility in response to events and agility in decision making. 
Finally, we can understand which are the main methodologies that are employed in studies on IT and organizational agility. It is noted that the application of the survey for data collection followed by an analysis using structural equation modelling (SEM) appeared as a highlight in terms of the methodology adopted in the sample analysed, ie, the analysis of the relationship of these two constructs. This is generally done through quantitative approaches.

\subsection{Co-citation network analysis}

Co-citation analysis allows us to identify the authors who are referenced in the sample articles, thereby identifying those most relevant groups of authors. For this, the VOSviewer software was used, which is compatible with Web of Science base extraction. The authors cited in at least 10 articles in the sample were selected, corresponding to approximately $21 \%$. At the end of processing, 20 authors were identified within this criterion, and they are presented in Figure 7.

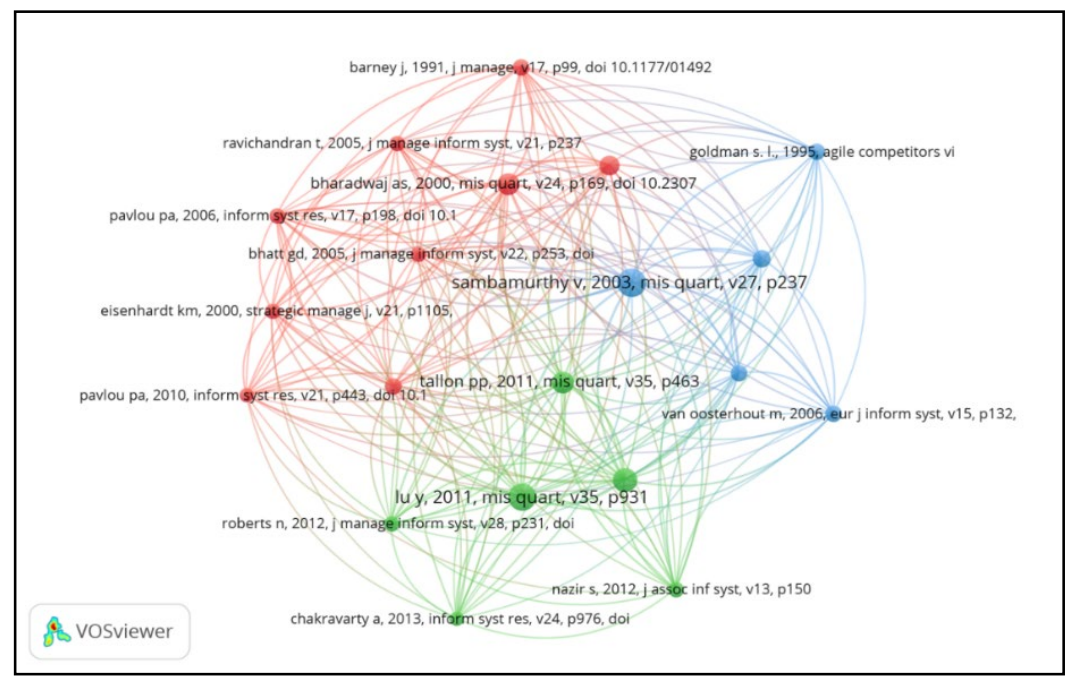

Figure 7. Cocitation network.

It is noted that 3 clusters were formed, and to understand each one of them, an analysis of the author's study that was most cited within each of the clusters was made. Thus, the articles analysed are presented in Table 1.

Table 1. Top Authors of Cocitation Analysis.

\begin{tabular}{cll}
\hline Cluster & \multicolumn{1}{c}{ Authors } & \multicolumn{1}{c}{ Article } \\
\hline Red & Bharadwaj (2000) & $\begin{array}{l}\text { A Resource-Based Perspective on Information } \\
\text { Technology Capability and Firm Performance: } \\
\text { An Empirical Investigation. }\end{array}$ \\
\hline Blue & Sambamurthy et al. (2003) & $\begin{array}{l}\text { Shaping Agility through Digital Options: } \\
\text { Reconceptualization the Role of IT in } \\
\text { Contemporary Firms }\end{array}$ \\
\hline Green & Lu \& Ramamurthy (2011) & $\begin{array}{l}\text { Understanding the Link Between Information } \\
\text { Technology Capability and Organizational } \\
\end{array}$ \\
& & Agility: An Empirical Examination \\
\hline
\end{tabular}




\subsubsection{IT and organizational performance from RBV perspective}

Bharadwaj (2000) employs the concepts covered by Resource-Based View (RBV), in which resources must be valuable, rare and difficult to imitate or replace, over information technology resources, which are considered as organizational capability. This study aimed to examine the relationship between information technology capacity and the performance of organizations. The result of this study identified a positive and significant effect on this relationship.

Results indicate that IT capability is an income-generating resource that is not easily imitated or replaced. A company's IT capability derives from underlying strengths: (1) IT infrastructure - provides the platform for launching IT application innovations faster than competitors; (2) IT human resources - enable companies to design and deploy these applications faster than competitors; (3) IT-enabled intangible assets - leveraging or exploiting the use of pre-existing intangible assets such as customer orientation and synergy.

\subsubsection{IT's role for contemporary businesses}

Sambamurthy et al. (2003) believe that agility is vital to the innovation process and the competitive performance of organizations in contemporary business environments. In their view, companies are increasingly relying on process, knowledge, and communication information technologies to increase their agility.

The authors sought to expand understanding of IT's strategic role by examining the nomological network of influences through which these resources impact organizational performance, considering the ideas addressed in the IT strategy, entrepreneurship, and management literature. Thus, Sambamurthy et al. (2003) provide a perspective to argue that IT investments and resources influence performance through three significant organizational capabilities (agility, digital options, and entrepreneurial alertness) and strategic processes (capacity building, entrepreneurial action, and adaptation).

They highlight a significant and reshaped role of IT as a digital options generator in contemporary businesses. Their definition of digital options is: "We describe digital options as a set of IT-enabled capabilities in the form of digitized corporate work processes and knowledge systems" (Sambamurthy et al., 2003, p. 247).

The first part is linked to the business processes that can be automated, computerized and integrated, and the second with the creation of a knowledge base that can be shared among the members of the organization, that is, generating a process of dissemination of the information. knowledge within the organization.

\subsubsection{The contradiction of organizational agility provided by IT}

For Lu \& Ramamurthy (2011), despite the common premise that increased IT investment enables a business to be more agile, it is not uncommon for IT to sometimes hinder organizational agility. In this context, the authors propose and theorize this contradiction of agility provided by IT that is frequently observed, but little studied, by which IT can allow or prevent agility.

The authors assume that organizations need to develop an IT capability, that is, successfully manage their IT resources for market capitalization agility and agile 
operational adjustments. The analysis of the collected data was made through an exploratory factor analysis followed by a confirmatory factor analysis.

The results obtained by Lu \& Ramamurthy (2011) show a significant positive relationship between IT capacity and the two types of organizational agility: operational adjustment agility and market capitalization agility. In addition, a significant positive combined effect of IT capacity and IT spending was identified on operational adjustment agility, but not on market capitalization agility. The authors suggest the following solution to the apparent paradox: simply spending more on IT does not necessarily lead to greater agility, but spending in ways that nurture and enhance IT capabilities does.

\subsubsection{Concluding remarks}

Bharadwaj's (2000) paper is a reference in the field of research involving information technology and organizational performance. The RBV approach used on IT resources is widespread over the years, as this study was referenced in subsequent articles of the analysis. The author defines the IT capability construct in three broad dimensions: (1) IT Infrastructure, (2) IT Human Resources, and (3) Intangible Resources enabled by IT.

It is in this last dimension that we can make a connection with the study by Sambamurthy et al. (2003), since digital options could be framed in this dimension. This becomes clearer when digital options involve knowledge-oriented issues, which would be one of the components of the IT-enabled resources dimension, in Bharadwaj's (2000) view, classified as a knowledge asset. Moreover, on the business process aspect, one could associate digital options with the synergy that is one of the aspects that Bharadwaj (2000) also fits within this dimension, in order to achieve greater efficiency of business processes. from the company. The same goes for the concepts that are presented by Sambamurthy et al. (2003) about the concept of agility.

But does an investment in IT resources really improve organizational agility? About this question, Lu \& Ramamurthy (2011) concluded that companies need to spend on IT in order to improve and foster IT capabilities, because it is these capabilities that have a direct influence on organizational agility.

\subsection{Content analysis}

After analysing the content of the articles listed in Appendix A, it was possible to group them into the main themes identified. The first group presented consists of articles that present models that seek to understand the relationship between information technology and organizational agility, and its possible consequences on organizational performance. The second group analyses the relationship between technology acceptance and its impact on organizational agility.

\subsubsection{Approaches to IT's impact on organizational agility}

We identified a set of studies focusing on presenting approaches to analyse the causal relationship between information technologies and organizational agility. A brief description of each study is given in Appendix $B$. 
Overall, the studies provide empirical evidence that IT capabilities as well as IT's strategic alignment with the business have a positive and significant impact on organizational agility.

Regarding the organizational agility construct, a variety of taxonomies can be noted, which demonstrates that a clear definition of this construct is necessary before starting a study to avoid possible confusion throughout a research. The same is true for the construct: IT capability.

In general, the research approach has a quantitative character in which data were collected through Surveys and data were analysed through factor analysis (exploratory or confirmatory), Partial Least Squares (PLS) or modelling structural equations.

An interesting aspect presented by Lu \& Ramamurthy (2011) for future studies is to examine how other elements such as culture, structure, process or people, interact with IT, providing agility. In addition, Tallon \& Pinsonneault (2011) draw attention to an opportunity to understand the issue of how organizational agility is maintained over time through its strategic alignment with the business. This idea is also highlighted by Fink \& Neumann. (2007).

Among information technologies, Big Data Analytics appears as a strategic investment that can contribute to organizational agility, especially assisting in the processing of data for knowledge generation that allows a more effective decision making (Côrte-Real et al., 2017).

Ayabakan et al. (2017) point out that models that study the relationship between information technology and organizational agility generally analyse (1) the direct effect of IT capabilities on agility, (2) the moderating effect of IT capabilities on the relationship between other organizational capabilities and organizational agility, and (3) the indirect effect of IT on organizational agility mediated by other organizational capabilities, such as the supply chain process-related capabilities highlighted by Liu et al. (2016).

\subsubsection{IT acceptance by the workforce}

The acceptance of the workforce on the use of information technology is an important issue to be analysed in the context of organizational agility. This refers to the proposal of the article by Breu et al. (2001) who comment on the importance of giving due attention to the workforce in addition to the high amount of studies focused on the organizational level. In addition, they highlight the importance of IT literacy in the agility of this workforce, which is comprised of a set of capabilities focused on intelligence, skills, collaboration, culture and information systems.

In this context, Zain et al. (2005) present a model with the objective of analysing the influence of IT acceptance on organizational agility. For this, the authors surveyed the data through a survey and performed the analysis of the data collected by the structural equation modelling technique. Following the analysis, the authors found empirical evidence that the actual use of information technology has a stronger direct effect on organizational agility. Perceived utility and perceived ease of use of IT influenced organizational agility indirectly through attitudes related to the use of technology. This result reinforces the importance of cultivating positive subjective norms for the use of IT, if all employees from management have a commitment to the use of IT, it will be possible to generate timely information for decision making processes in turbulent environments.

Chung et al. (2014) present a similar approach, in which they consider that workers' perception of the organizational agility that an information technology tool can provide, 
can significantly influence its use due to positive beliefs of what this technology can provide. These authors analysed the use of mobile business systems, and the results reinforce the positive and significant effect of the relationship analysed and the importance of technology acceptance by employees.

\section{Conclusions}

There has been a significant growth in studies involving these two constructs, approximately $275 \%$ in the last four years, which may be an indicator that this theme is beginning to mature in the literature and is increasingly becoming the focus of researchers.

A large concentration of studies focusing on this topic in the United States was evidenced, and the most recent publications generally occurred in journals with a greater impact factor in the literature on management and management of information systems.

These studies provide evidence that indicates a positive IT relationship on organizational agility, either directly or indirectly. This synergy can provide in building competitive advantages for organizations. Moreover, it is noted that studies that relate these two constructs have a strong foundation on strategic theories that are oriented to the internal environment of the organization, ie, seeking to understand how the use of resources that an organization can contribute to achieve competitive advantage.

Regarding organizational agility construct, it was possible to notice a wide variety of taxonomies, as highlighted in the Content Analysis Operational Framework for Research Models presented in Appendix B. In general, organizational agility can be understood as the ability of the organization to detect events (sensitivity), so that the company can respond quickly to environmental demands (responsiveness) through more efficient and effective decision making. It is then noted that organizational agility consists of three major pillars that must be analysed together: sensitivity, decision and responsiveness.

Among the main themes identified are the studies that present causal relationship approaches between the two constructs and the organization's performance, where information technologies are seen as capabilities that can directly or indirectly influence organizational agility, and fit in the idea presented by Ayabakan et al. (2017) that these approaches generally analyse (1) the direct effect of IT capabilities on agility, (2) the moderating effect of IT capabilities on the relationship between other organizational capabilities and organizational agility, and (3) the indirect effect of IT on organizational agility mediated by other organizational capabilities.

One opportunity for future studies is to empirically validate the taxonomy identified during this study for organizational agility that is the composition of three aspects: sensitivity, decision, and responsiveness. Thus, it would be interesting to have more studies that also identified the impact of emerging information technologies on each of these aspects.

\section{References}

Ayabakan, S., Bardhan, I., \& Zheng, Z. (2017). A data envelopment analysis approach to estimate IT-enabled production capability. MIS Quaterly, 41(1), 189-205.

http://dx.doi.org/10.25300/MISQ/2017/41.1.09. 
Bharadwaj, A. (2000). A resource-based perspective on information technology capability and firm performance: an empirical investigation. Management Information Systems Quarterly, 24(1), 169-196. http://dx.doi.org/10.2307/3250983.

Breu, K., Hemingway, C., Strathern, M., \& Bridger, D. (2001). Workforce agility: the new employee strategy for the knowledge economy. Journal of Information Technology, 17(1), 21-31. http://dx.doi.org/10.1080/02683960110132070.

Carvalho, M. M., Fleury, A., \& Lopes, A. P. (2013). An overview of the literature on technology roadmapping (TRM): contributions and trends. Technological Forecasting and Social Change, 80(7), 1418-1437. http://dx.doi.org/10.1016/j.techfore.2012.11.008.

Chakravarty, A., Grewal, R., \& Sambamurthy, V. (2013). Information technology competencies, organizational agility, and firm performance: enabling and facilitating roles. Information Systems Research, 24(4), 967-997. http://dx.doi.org/10.1287/isre.2013.0500.

Chen, H., Chiang, R. H. L., \& Storey, V. C. (2012). Business intelligence and analytics: from big data to big impact. Management Information Systems Quarterly, 36(4), 1165-1188. http://dx.doi.org/10.2307/41703503.

Chung, S., Lee, K., \& Kim, K. (2014). Job performance through mobile enterprise systems. Information \& Management, 51(6), 605-617. http://dx.doi.org/10.1016/j.im.2014.05.007.

Côrte-Real, N., Oliveira, T., \& Ruivo, P. (2017). Assessing business value of Big Data Analytics in European firms. Journal of Business Research, 70, 379-390. http://dx.doi.org/10.1016/j.jbusres.2016.08.011.

Felipe, C., Roldán, J., \& Leal-Rodríguez, A. (2016). An explanatory and predictive model for organizational agility. Journal of Business Research, 69(10), 4624-4631. http://dx.doi.org/10.1016/j.jbusres.2016.04.014.

Fink, L., \& Neumann, S. (2007). Gaining agility through IT personnel capabilities: the mediating role of IT infrastructure capabilities. Journal of the Association for Information Systems, 8(8), 440-462. http://dx.doi.org/10.17705/1jais.00135.

Lee, O.-K. D., Sambamurthy, V., Lim, K. H., \& Wei, K. K. (2015). How does it ambidexterity impact organizational agility? Information Systems Research, 16(2), 398-417. http://dx.doi.org/10.1287/isre.2015.0577.

Liu, H., Wei, S., Ke, W., Wei, K., \& Hua, Z. (2016). The configuration between supply chain integration and information technology competency: a resource orchestration perspective. Journal of Operations Management, 44(1), 13-29. http://dx.doi.org/10.1016/j.jom.2016.03.009.

Lu, Y., \& Ramamurthy, K. (2011). Understanding the link between information technology capability and organizational agility: an empirical examination. Management Information Systems Quarterly, 35(4), 931-954. http://dx.doi.org/10.2307/41409967.

Sambamurthy, Bharadwaj, A.,\& Grover, V. (2003). Shaping agility through digital options: reconceptualization the role of it in contemporary firms. Management Information Systems Quarterly, 27(2), 237-265. http://dx.doi.org/10.2307/30036530.

Tallon, P. P., \& Pinsonneault, A. (2011). Competing perspectives on the link between strategic information technology alignment and organizational agility: insights from a mediation model. Management Information Systems Quarterly, 35(2), 463-486. http://dx.doi.org/10.2307/23044052.

Zain, M., Rose, R., Abdullah, I., \& Masrom, M. (2005). The relationship between information technology acceptance and organizational agility in Malaysia. Information \& Management, 42(6), 829-839. http://dx.doi.org/10.1016/j.im.2004.09.001. 


\section{Appendix A. List of Articles Considered in Content Analysis.}

Table 1A. Article List (Content Analysis).

\begin{tabular}{|c|c|c|}
\hline Title & Authors & Year \\
\hline $\begin{array}{l}\text { Workforce agility: the new employee strategy for } \\
\text { the knowledge economy }\end{array}$ & $\begin{array}{l}\text { Breu, K., Hemingway, } \\
\text { C., Strathern, M., \& } \\
\text { Bridger, D. }\end{array}$ & 2002 \\
\hline $\begin{array}{l}\text { The relationship between information technology } \\
\text { acceptance and organizational agility in Malaysia }\end{array}$ & $\begin{array}{l}\text { Zain, M., Rose, R., } \\
\text { Abdullah, I., \& Masrom, M. }\end{array}$ & 2005 \\
\hline $\begin{array}{l}\text { Gaining agility through IT personnel capabilities: } \\
\text { The mediating role of IT infrastructure capabilities }\end{array}$ & Fink, L., \& Neumann, S. & 2007 \\
\hline $\begin{array}{l}\text { Competing perspectives on the link between } \\
\text { strategic information technology alignment and } \\
\text { organizational agility: insights from a mediation } \\
\text { model }\end{array}$ & $\begin{array}{l}\text { Tallon, P. P., \& } \\
\text { Pinsonneault, A. }\end{array}$ & 2011 \\
\hline $\begin{array}{l}\text { Understanding the link between information } \\
\text { technology capability and organizational agility: an } \\
\text { empirical examination }\end{array}$ & Lu, Y., \& Ramamurthy, K. & 2011 \\
\hline $\begin{array}{l}\text { Information Technology Competencies, } \\
\text { Organizational Agility, and Firm Performance: } \\
\text { Enabling and Facilitating Roles }\end{array}$ & $\begin{array}{l}\text { Chakravarty, A., Grewal, } \\
\text { R., \& Sambamurthy, V. }\end{array}$ & 2013 \\
\hline $\begin{array}{l}\text { Job performance through mobile enterprise } \\
\text { systems: The role of organizational agility, location } \\
\text { independence, and task characteristics }\end{array}$ & $\begin{array}{l}\text { Chung, S., Lee, K., \& } \\
\text { Kim, K. }\end{array}$ & 2014 \\
\hline $\begin{array}{l}\text { How Does IT Ambidexterity Impact Organizational } \\
\text { Agility? }\end{array}$ & $\begin{array}{l}\text { Lee, O., Sambamuthy, } \\
\text { V., Lim, K., \& Wei, K. }\end{array}$ & 2015 \\
\hline $\begin{array}{l}\text { An explanatory and predictive model for } \\
\text { organizational agility }\end{array}$ & $\begin{array}{l}\text { Felipe, C., Roldán, J., \& } \\
\text { Leal-Rodríguez, A. }\end{array}$ & 2016 \\
\hline $\begin{array}{l}\text { The configuration between supply chain integration } \\
\text { and information technology competency: A } \\
\text { resource orchestration perspective }\end{array}$ & $\begin{array}{l}\text { Liu, H., Wei, S., Ke, W., } \\
\text { Wei, K., \& Hua, Z. }\end{array}$ & 2016 \\
\hline $\begin{array}{l}\text { A data envelopment analysis approach to estimate } \\
\text { IT-enabled production capability }\end{array}$ & $\begin{array}{l}\text { Ayabakan, S., Bardhan, } \\
\text { I., \& Zheng, Z. }\end{array}$ & 2017 \\
\hline $\begin{array}{l}\text { Assessing business value of Big Data Analytics in } \\
\text { European firms }\end{array}$ & $\begin{array}{l}\text { Côrte-Real, N., Oliveira, } \\
\text { T., \& Ruivo, P. }\end{array}$ & 2017 \\
\hline
\end{tabular}




\section{Appendix B. Content Analysis Operational Framework for Search Models.}

Table 1B. Research Models Operational Framework.

\begin{tabular}{|c|c|c|c|c|c|}
\hline Authors & Goal & Constructs & Methodology & Results & $\begin{array}{l}\text { Future } \\
\text { Research }\end{array}$ \\
\hline \multirow[t]{9}{*}{$\begin{array}{l}\text { Fink \& Neumann } \\
(2007)\end{array}$} & \multirow{9}{*}{$\begin{array}{l}\text { Present a } \\
\text { model for } \\
\text { analyzing how } \\
\text { technical, } \\
\text { behavioral, } \\
\text { and business } \\
\text { resources are } \\
\text { associated IT } \\
\text { with } \\
\text { infrastructure } \\
\text { resources and } \\
\text { how they are } \\
\text { associated } \\
\text { with IT- } \\
\text { dependent } \\
\text { organizational } \\
\text { agility. }\end{array}$} & $\begin{array}{l}\text { (1) IT } \quad \text { staff } \\
\text { capabilities }\end{array}$ & $\begin{array}{l}\text { (1) } \\
\text { Quantitative } \\
\text { Approach }\end{array}$ & $\begin{array}{l}\text { (1) The IT staff's } \\
\text { behavioral and } \\
\text { technical } \\
\text { resources have } \\
\text { a positive effect } \\
\text { on infrastructure } \\
\text { capabilities. }\end{array}$ & \multirow{9}{*}{$\begin{array}{l}\text { (1) Address the } \\
\text { time dimension } \\
\text { in studying the } \\
\text { strategic value } \\
\text { of shared IT } \\
\text { capabilities, } \\
\text { preferably using } \\
\text { qualitative } \\
\text { methodologies. }\end{array}$} \\
\hline & & - business ability & (2) Survey & $\begin{array}{l}\text { (2) The effect of } \\
\text { infrastructure } \\
\text { resources on IT- } \\
\text { dependent } \\
\text { strategic agility } \\
\text { is } \\
\text { straightforward, } \\
\text { as well as } \\
\text { mediated by IT- } \\
\text { dependent } \\
\text { system and } \\
\text { information } \\
\text { agility. }\end{array}$ & \\
\hline & & - behavioral & $\begin{array}{l}\text { (3) Structural } \\
\text { equation } \\
\text { modeling }\end{array}$ & & \\
\hline & & - technical ability & & & \\
\hline & & $\begin{array}{l}(2) \\
\text { Infrastructure }\end{array}$ & & & \\
\hline & & $\begin{array}{l}\text { (3) IT-dependent } \\
\text { organizational } \\
\text { agility }\end{array}$ & & & \\
\hline & & - Strategic Agility & & & \\
\hline & & - System Agility & & & \\
\hline & & - Inility & & & \\
\hline \multirow[t]{5}{*}{$\begin{array}{l}\text { Tallon } \\
\text { Pinsonneault } \\
\text { (2011) }\end{array}$} & \multirow{5}{*}{$\begin{array}{l}\text { Present a } \\
\text { model in which } \\
\text { organizational } \\
\text { agility is seen } \\
\text { as a mediating } \\
\text { factor between } \\
\text { IT strategic } \\
\text { alignment and } \\
\text { organizational } \\
\text { performance. } \\
\text { And IT } \\
\text { flexibility is } \\
\text { seen as } \\
\text { moderating } \\
\text { this } \\
\text { relationship. }\end{array}$} & $\begin{array}{l}\text { (1) IT's strategic } \\
\text { alignment }\end{array}$ & $\begin{array}{l}\text { (1) } \\
\text { Quantitative } \\
\text { Approach }\end{array}$ & $\begin{array}{l}\text { (1) Positive and } \\
\text { meaningful } \\
\text { relationship } \\
\text { between } \\
\text { strategic } \\
\text { alignment and } \\
\text { organizational } \\
\text { agility and } \\
\text { business agility. }\end{array}$ & \multirow[t]{5}{*}{$\begin{array}{l}\text { (1) Understand } \\
\text { how IT strategic } \\
\text { alignment } \\
\text { enables agility } \\
\text { over time and } \\
\text { how success or } \\
\text { lack of agility } \\
\text { contributes to } \\
\text { future alignment } \\
\text { decisions. }\end{array}$} \\
\hline & & (2) IT Flexibility & (2) Survey & $\begin{array}{l}\text { (2) Flexibility of } \\
\text { IT infrastructure } \\
\text { has a major } \\
\text { positive and } \\
\text { significant effect } \\
\text { on agility. }\end{array}$ & \\
\hline & & $\begin{array}{l}\text { (3) } \\
\text { Organizational } \\
\text { agility }\end{array}$ & $\begin{array}{l}(3) \\
\text { Confirmatory } \\
\text { Factor } \\
\text { Analysis }\end{array}$ & & \\
\hline & & $\begin{array}{l}\text { - responsiveness } \\
\text { to consumers }\end{array}$ & & & \\
\hline & & $\begin{array}{l}\text { - agility in } \\
\text { relationships with }\end{array}$ & & & \\
\hline
\end{tabular}




\begin{tabular}{|c|c|c|c|c|c|}
\hline Authors & Goal & Constructs & Methodology & Results & $\begin{array}{l}\text { Future } \\
\text { Research }\end{array}$ \\
\hline & & $\begin{array}{l}\text { business } \\
\text { partners }\end{array}$ & & & \\
\hline & & $\begin{array}{l}\text { agility } \\
\text { operational }\end{array}$ & & & \\
\hline & & $\begin{array}{l}(4) \\
\text { Organizational } \\
\text { performance }\end{array}$ & & & \\
\hline & & $\begin{array}{l}(5) \\
\text { Environmental } \\
\text { volatility }\end{array}$ & & & \\
\hline \multirow[t]{7}{*}{$\begin{array}{l}\text { Lu \& Ramamurthy } \\
\text { (2011) }\end{array}$} & \multirow{7}{*}{$\begin{array}{l}\text { (1) Does IT } \\
\text { capacity } \\
\text { increase or } \\
\text { hinder agility? } \\
\text { (2) How does } \\
\text { IT capability } \\
\text { complement } \\
\text { other } \\
\text { organizational } \\
\text { resources, ie } \\
\text { IT spending, to } \\
\text { increase } \\
\text { organizational } \\
\text { agility? }\end{array}$} & $\begin{array}{l}(1) \\
\text { Organizational } \\
\text { agility }\end{array}$ & $\begin{array}{l}\text { (1) } \\
\text { Quantitative } \\
\text { Approach }\end{array}$ & $\begin{array}{l}\text { (1) Significant } \\
\text { positive } \\
\text { relationship } \\
\text { between IT } \\
\text { capability and } \\
\text { both types of } \\
\text { organizational } \\
\text { agility. }\end{array}$ & \multirow{7}{*}{$\begin{array}{l}\text { (1) Extend this } \\
\text { research and } \\
\text { examine how } \\
\text { other elements } \\
\text { such as culture, } \\
\text { structure, } \\
\text { process, or } \\
\text { people interact } \\
\text { with IT, } \\
\text { enabling agility. }\end{array}$} \\
\hline & & $\begin{array}{l}\text { - market capture } \\
\text { agility }\end{array}$ & (2) Survey & $\begin{array}{l}\text { (2) While more } \\
\text { IT spending } \\
\text { does not lead to } \\
\text { greater agility, } \\
\text { spending it to } \\
\text { enhance and } \\
\text { nurture IT } \\
\text { capabilities can } \\
\text { improve } \\
\text { organizational } \\
\text { agility. }\end{array}$ & \\
\hline & & $\begin{array}{l}\text { - operational } \\
\text { adjustment agility }\end{array}$ & $\begin{array}{l}\text { (3) Exploratory } \\
\text { and } \\
\text { confirmatory } \\
\text { factor } \\
\text { analysis. }\end{array}$ & & \\
\hline & & (2) IT capability & & & \\
\hline & & - IT infrastructure & & & \\
\hline & & - Business scope & & & \\
\hline & & $\begin{array}{l}\text { - Proactive IT } \\
\text { Positioning }\end{array}$ & & & \\
\hline \multirow[t]{3}{*}{$\begin{array}{l}\text { Chakravarty et al. } \\
(2013)\end{array}$} & \multirow{3}{*}{$\begin{array}{l}\text { Understand } \\
\text { how } \\
\text { information } \\
\text { technology } \\
\text { skills shape } \\
\text { organizational } \\
\text { agility and } \\
\text { company } \\
\text { performance } \\
\text { while } \\
\text { considering } \\
\text { environmental } \\
\text { dynamism. }\end{array}$} & $\begin{array}{l}(1) \quad \text { IT } \\
\text { competencies } \\
\text { are addressed } \\
\text { through two } \\
\text { roles: }\end{array}$ & $\begin{array}{l}\text { (1) } \\
\text { Quantitative } \\
\text { Approach }\end{array}$ & $\begin{array}{l}\text { (1) The enabling } \\
\text { and enabling } \\
\text { effects of IT } \\
\text { skills vary } \\
\text { according to the } \\
\text { dynamism of the } \\
\text { environment. }\end{array}$ & \multirow[t]{3}{*}{$\begin{array}{l}\text { (1) Consider the } \\
\text { role of sourcing } \\
\text { capabilities as } \\
\text { another } \\
\text { competency. }\end{array}$} \\
\hline & & - Enabler & (2) Survey & $\begin{array}{l}\text { (2) Associations } \\
\text { between IT } \\
\text { competencies, } \\
\text { organizational } \\
\text { agility, and } \\
\text { company } \\
\text { performance } \\
\text { are } \\
\text { uniformly not } \\
\text { applicable to all } \\
\text { companies. }\end{array}$ & \\
\hline & & - Facilitator & $\begin{array}{l}(3) \quad \text { Latent } \\
\text { class } \\
\text { regression } \\
\text { analysis. }\end{array}$ & & \\
\hline
\end{tabular}




\begin{tabular}{|c|c|c|c|c|c|}
\hline Authors & Goal & Constructs & Methodology & Results & $\begin{array}{l}\text { Future } \\
\text { Research }\end{array}$ \\
\hline & & $\begin{array}{l}\text { (2) } \\
\text { Organizational } \\
\text { Agility }\end{array}$ & & & \\
\hline & & - Adaptive Agility & & & \\
\hline & & $\begin{array}{l}\text { - Entrepreneurial } \\
\text { agility }\end{array}$ & & & \\
\hline \multirow[t]{8}{*}{ Lee et al. (2015) } & $\begin{array}{l}\text { (1) Examine } \\
\text { the process of } \\
\text { building a } \\
\text { company's } \\
\text { capabilities } \\
\text { facilitated by } \\
\text { IT } \\
\text { ambidexterity, } \\
\text { which leads to } \\
\text { organizational } \\
\text { agility. How } \\
\text { does IT } \\
\text { ambidexterity } \\
\text { increase } \\
\text { organizational } \\
\text { agility within a } \\
\text { company? }\end{array}$ & $\begin{array}{l}(1) \\
\text { Organizational } \\
\text { Agility }\end{array}$ & $\begin{array}{l}\text { (1) } \\
\text { Quantitative } \\
\text { Approach }\end{array}$ & $\begin{array}{l}\text { (1) IT } \\
\text { ambidexterity } \\
\text { increases } \\
\text { organizational } \\
\text { agility through } \\
\text { the mediated } \\
\text { effects of } \\
\text { operational } \\
\text { ambidexterity. }\end{array}$ & $\begin{array}{l}\text { (1) Study the } \\
\text { role of IT for } \\
\text { different } \\
\text { business } \\
\text { conditions. }\end{array}$ \\
\hline & $\begin{array}{l}\text { (2) Examine } \\
\text { the specific } \\
\text { environmental } \\
\text { conditions of } \\
\text { the underlying } \\
\text { mechanisms } \\
\text { for IT-enabled } \\
\text { agility building. } \\
\text { How does the } \\
\text { company's } \\
\text { business } \\
\text { environment } \\
\text { affect the } \\
\text { enabling } \\
\text { processes } \\
\text { between IT } \\
\text { ambidexterity } \\
\text { and } \\
\text { organizational } \\
\text { agility? }\end{array}$ & - Proactivity & (2) Survey & $\begin{array}{l}\text { (2) The } \\
\text { dynamism of a } \\
\text { company's } \\
\text { environment } \\
\text { affects this } \\
\text { relationship. }\end{array}$ & $\begin{array}{l}\text { (2) Study other } \\
\text { moderating or } \\
\text { mediating } \\
\text { factors as } \\
\text { characteristics } \\
\text { of senior } \\
\text { management } \\
\text { and entrepreneurial } \\
\text { perception. }\end{array}$ \\
\hline & & - Radicality & $\begin{array}{l}\text { (3) Structural } \\
\text { equation } \\
\text { modeling }\end{array}$ & & \\
\hline & & ' & & & \\
\hline & & - Adaptability & & & \\
\hline & & $\begin{array}{ll}(2) & \text { IT } \\
\text { Ambidexterity }\end{array}$ & & & \\
\hline & & $\begin{array}{l}\text { - Simultaneously } \\
\text { explore new IT } \\
\text { resources and } \\
\text { practices } \\
\text { exploitation) as } \\
\text { well as exploit } \\
\text { your current IT } \\
\text { resources and } \\
\text { practices } \\
\text { exploitation) }\end{array}$ & & & \\
\hline & & $\begin{array}{l}\text { (3) Operating } \\
\text { Ambidexterity }\end{array}$ & & & \\
\hline
\end{tabular}




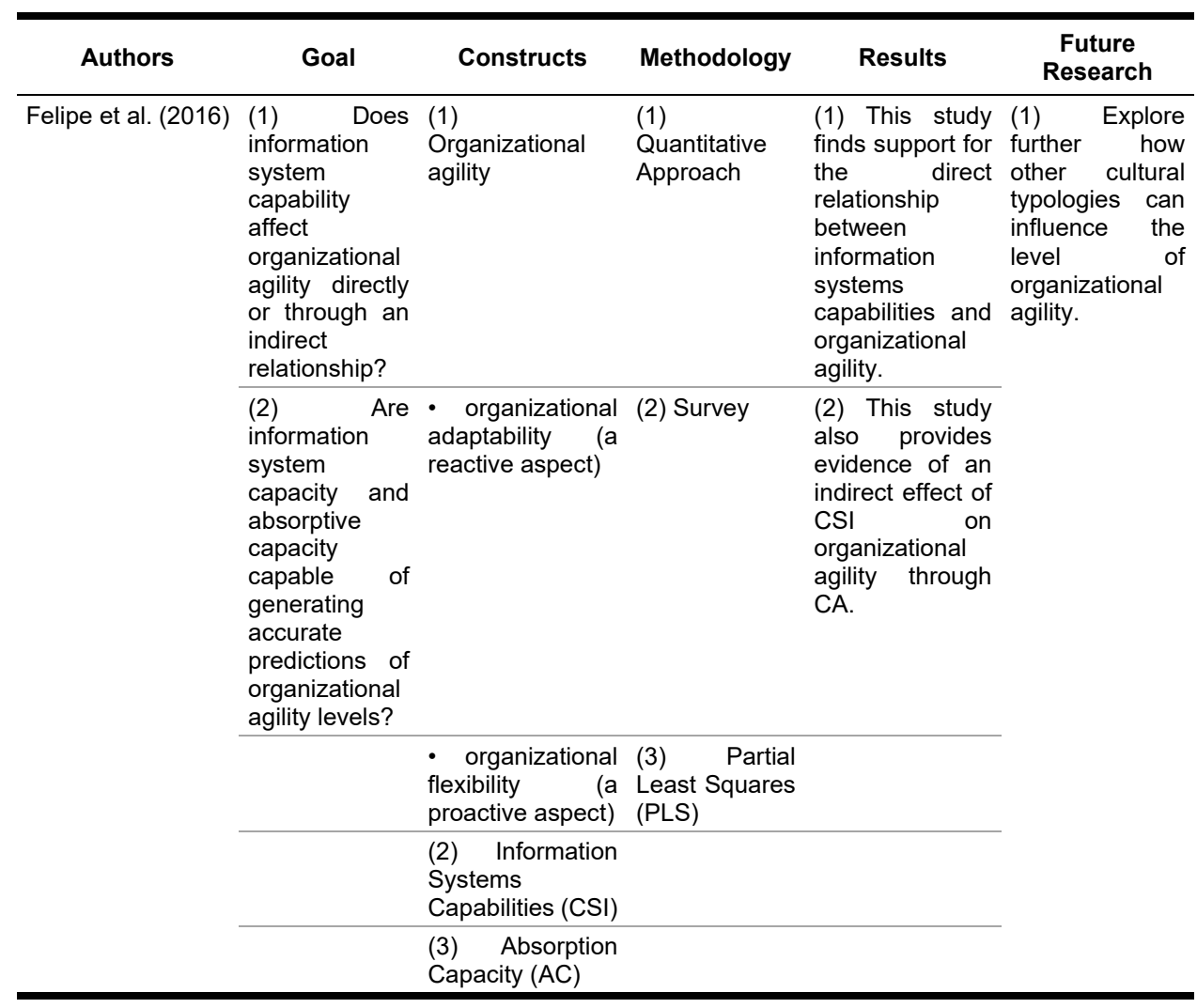

